\title{
ANALYSIS OF CHARACTERISTICS OF SEVERAL BENDS ON SIDOAN RIVER
}

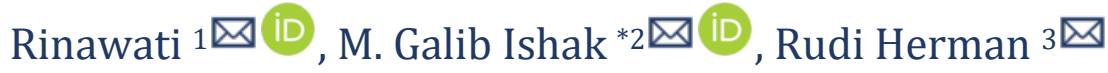 \\ 1, 2, 3 Department of Civil Engineering. Engineering Faculty. University of Tadulako, Indonesia
}

DOI: https://doi.org/10.29121/ijetmr.v8.i4.2021.927

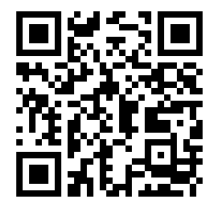

Article Citation: Rinawati, M. Galib Ishak, and Rudi Herman. (2021). ANALYSIS OF CHARACTERISTICS OF SEVERAL BENDS ON SIDOAN RIVER. International Journal of Engineering Technologies and Management Research, 8(4), 46-57. https://doi.org/10.29121/ijetmr.v8 i4 2021.927

Published Date: 24 April 2021

Keywords: Characteristics Q50 Sediment Motion Meandering River Shear Stress

\begin{abstract}
Researching the behavior of the river. Especially at the bend, where the morphology of the river is not always straightforward. Flow velocity high water and grinding at river bends occur at different points. This research was conducted on five adjacent bends on the Sidoan River section. This study examined the condition of riverbed sediment, knowing the stability of riverbed sediment granules based on shearing velocity, and stability of riverbed sediment granules based on shear stress. The method used in this study is geometric measurement. $Q_{50}$ discharge calculation. produces hydraulic simulation. $d_{50}$ sediment diameter. HEC-RAS software simulation and Shields graphs analysis. The results of the study on five bends for $\mathrm{Q}_{50}$ discharge are the condition of the riverbed in five bends all moving, the critical shear velocity relationship and flow depth are directly proportional, the highest condition at bend 2, otherwise the lowest condition at bend 3. The relationship between particle dimensions and shear velocity is inversely proportional to the value of sliding velocity. if the particle dimensions are small then the large shear stress occurs at bend 5 and vice versa, the dimensions of large particles then the small shear velocity occurs at bend 4 , sliding velocity is directly proportional to the shear stress. The highest critical shear stress at bend 2, while the lowest condition at bend 4 , the greater the radius of the bend the scouring was deeper.
\end{abstract}

\section{INTRODUCTION}

Researching the behavior of the flow at the bends of the river is very important because the morphology of the river is not always straight so that the flow-through can be affected by the bend. The meandering river is a dynamic system and very nonlinear. Sidoan River has a groove that bends. as shown in Figure 1 below that on the outside of the bend there is a scouring which is certainly caused by the presence of centrifugal force flow.

At certain times large discharges and flow velocity are prone to overflow and scouring at river bends. Scouring of sediment and deposition on rivers can occur at different points, of the many bends found on the Sidoan River, and used five adjacent bends as a research object. This study examined the condition of riverbed sediment at five bends, knowing the stability of riverbed sediment granules based on sliding velocity. 


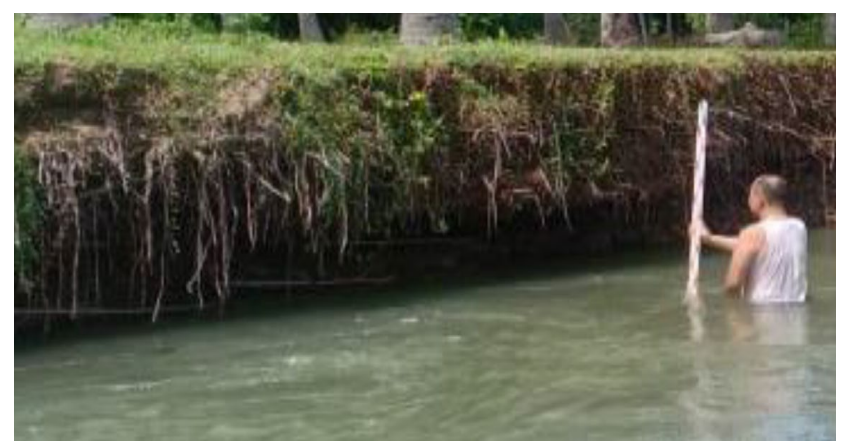

Figure 1: One of the bends on the Sidoan River.

According to Rinaldi [1] Researching the bend, especially about the depth of the scouring around the bridge abutment, stated that the scouring occurred due to the changing flow pattern, other researchers [2] researching the amount of scouring that occurs at the bends of the river, especially when there are pillars or abutments at the bend, this study was conducted in the laboratory, while another research examines the relationship between discharge and river meandering of geometry [3].

Marttotorang [4] observing the effect of riverbed width on flow patterns that occur in each section due to changes in flow velocity, with increasing flow velocity in the cross-section, sediment transport becomes large. Other research on bedload sediment [5],[6] conducted in the laboratory and the field. the results of research on the velocity and number of sediment particles show a logarithmic relationship to the average size of the sediment, the base material transport rate of the river width unity increases with increasing depth of the geometric equation function, and other studies [7],[8] the movement of sediment particles is also greatly influenced by the shape of the river basin.

Analyze the distribution of velocity and sediment in the channel bends, especially single bends [9],[10],[11] flow velocity increases on the inside of the bend when passing through the start of the bend, and velocity decreases at the end of the bend. Other research on the relationship between riverbed material characteristics and its geometry shows that the middle part of the river has the most content in coarse-grained soil $(\mathrm{d} \geq 0.150 \mathrm{~mm})$ while on the riverbanks the most content is fine-grained soil $(\mathrm{d} \leq 0.150 \mathrm{~mm})[12],[13]$.

Purnama [9] the distribution trends of the suspended sediment concentration increase towards the bottom of the channel and decreases towards the water surface with the distribution trend getting erect with a more uniform value towards the water surface. The discharge and flow velocity are directly proportional to the increase in the volume of scouring that occurs [13].

\section{MATERIALS AND METHODS}

\subsection{HYDROLOGY}

This research begins by collecting hydrological data, with this data calculated the rain intensity is the height of rain or the volume of rain per unit of time. The amount of rain intensity varies, depending on the length of rainfall and the frequency of its occurrence, and frequency analysis. This frequency analysis is intended to determine the relationship between the magnitude of extreme events and the frequency of the occurrence of these events, frequency analysis is needed. Frequency analysis for rainfall, in general, can be done using the frequency analysis of the Log Pearson III Distribution. Meanwhile, to determine which empirical frequency distribution method fits the existing data sample, statistical testing is required.

Rain intensity for a short duration was estimated using the Mononobe formula [14].

$$
I_{t}=\frac{R_{24}}{24}\left(\frac{24}{t}\right)^{2 / 3}
$$




\subsection{HYDROGRAPH}

According to Triatmodjo [15], a hydrograph is a curve that gives a relationship between flow parameters in the form of flow rate or water level with time. The hydrograph consists of a rising limb, peak, and recession limb, shown in Figure 2.

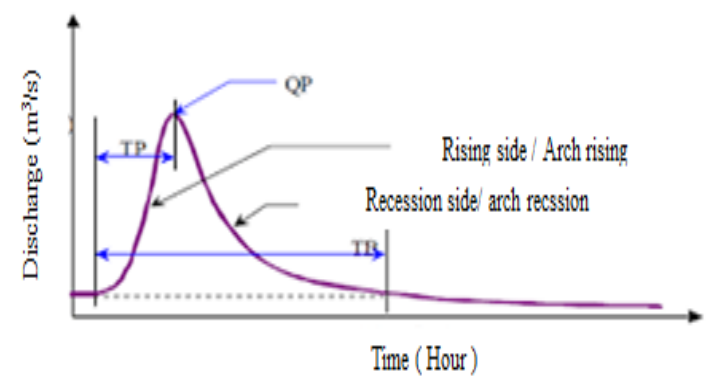

Figure 2: Components of the hydrograph [15].

\subsection{AMOUNT OF DISCHARGE}

To determine the amount of river discharge based on rain. it is necessary to examine the relationship between rain and river flow. The amount of flow in the river is determined mainly by the amount of rain, the intensity of the rain, the area of the rain area. the length of time of the rain, the area of the river, and the characteristics of the watershed [16].

\subsection{METHOD OF NAKAYASU}

Equation of HSS Nakayasu and Figure 3 [15].

$$
Q_{p}=\frac{1}{36}\left(\frac{A R_{e}}{0.3 T_{p}+T_{0.3}}\right)
$$

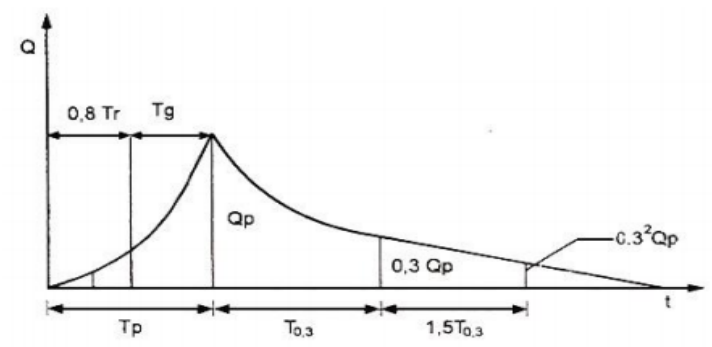

Figure 3: Graph of HSS Nakayasu [15].

\subsection{RIVER MORPHOLOGY}

Hay [17] assesses that the behavior of the river is meandering as shown in Figure 4.

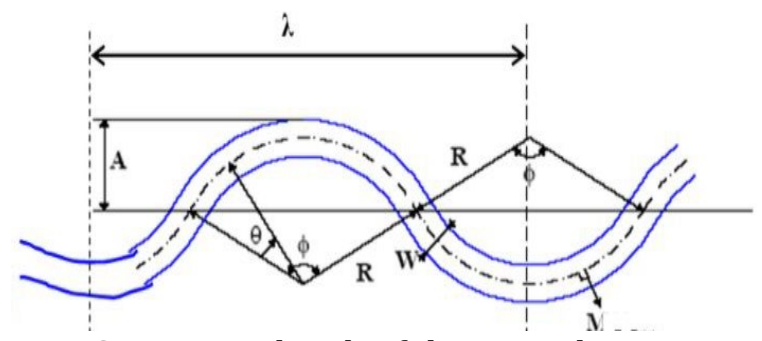

Figure 4: Geometry sketch of the meandering river [18]. 
Morisawa [19] formulated that the classification of bends is the ratio between the length of the flow of the meander and the length of the axis of the bend.

$\mathrm{SI}=$ the length of the river flow at the bend divided by the length of the axis of the bend, if $\mathrm{SI}<1.05=$ straight river. $\mathrm{SI}>1.5=$ meandering river, and $0.5>\mathrm{SI}<1.5=$ sinuous river.

\subsection{FACTORS AFFECTING THE DEPTH OF SCOUR}

Shields's diagram states the relationship between $U *^{2}=\nabla g d$, and number of Reynold $\left(R_{e}\right)$. Shields's graph is often used to evaluate the critical shear stress, as in Figure 5, by knowing the Reynolds number $\left(R_{e}\right)$ of grain or grain diameter $(d)$, then the critical shear stress value $\left(\tau_{c}\right)$ can be seen. If the bottom shear stress of the flow is above the critical value, then the sediment grains move, or in other words: $\tau_{o}<\tau_{c}$ the bottom grains moved.

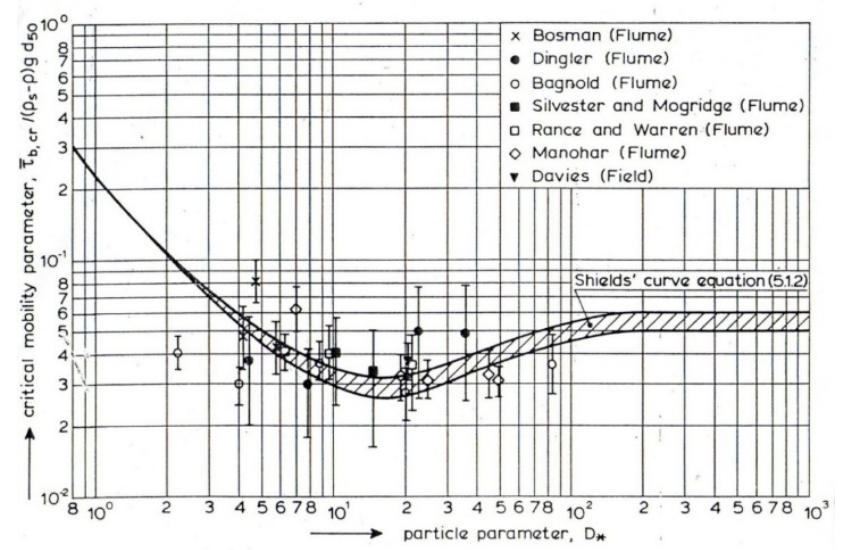

Figure 5: Shields Graph [20].

Shields's graph defined the initial motion to be the following equation:

$$
\begin{aligned}
& \theta_{c}=\frac{\tau_{c}}{\rho \cdot g \cdot d}=\frac{U_{*}}{\nabla g \cdot d} \\
& \nabla=\frac{\rho_{s}-\rho_{w}}{\rho_{w}}
\end{aligned}
$$

Shear velocity:

$$
U_{*}=\sqrt{g \cdot H \cdot I}
$$

Shear stress:

$$
\tau_{0}=\rho \cdot U_{*}^{2}
$$

\subsection{SIMULATION OF HEC-RAS 5.0}

HEC-RAS is an integrated package. designed for interactive use in multi-tasking environments. The HEC-RAS is an integrated package. designed for interactive use in multi-tasking environments. This system is designed to provide two-dimensional river modeling using steady flow, steady flow, and sediment transport calculations based on a geometric representation of the river network. Provides steady-flow surface water profile calculations for river networks with sub-critical. Supercritical, or mixed flow regimes [21]. HEC-RAS has four components of a onedimensional model: steady-flow water level profile count, unstable flow simulation, sediment transport count, and water quality counts. 


\subsection{BEDLOAD ROUGHNESS}

Sediment grain size classification refers to the Scale American Society of Testing Material (ASTM) Table 1. Roughness coefficient [22].

$n=0.038 d_{90}^{1 / 6}$

Roughness coefficient [23].

$n=0.047 d_{50}^{1 / 6}$

Roughness coefficient [24].

$n=0.031 d_{75}^{1 / 6}$

Table 1: The scale of the American Society of Testing Material (ASTM).

\begin{tabular}{|c|c|}
\hline Type & Size Range \\
\hline Chunks & $>256 \mathrm{~mm}$ \\
Rubble & $64-256 \mathrm{~mm}$ \\
Crust & $4-64 \mathrm{~mm}$ \\
Gravel & $2-4 \mathrm{~mm}$ \\
Very coarse sand, Rough sands & $1-2 \mathrm{~mm}$ \\
Medium sand & $0.5-1 \mathrm{~mm}$ \\
Fine sand & $0.25-0.5 \mathrm{~mm}$ \\
Very fine sand & $0.125-0.25 \mathrm{~mm}$ \\
Silt & $0.063-0.125 \mathrm{~mm}$ \\
Clay/Clays & $0.0039-0.063 \mathrm{~mm}$ \\
& $<0.0039 \mathrm{~mm}$ \\
\hline
\end{tabular}

Manning roughness figure is a coefficient value indicating the roughness of a channel or river bed either on the side or bottom of the channel or river. The Manning roughness value has a relationship to the flow velocity that occurs in a section. The greater the Manning roughness number, the smaller the flow velocity in a section, and vice versa, the smaller the Manning roughness number, the greater the flow velocity that occurs in a section.

\section{RESULTS AND DISCUSSIONS}

Rainfall data were analyzed to obtain a design flood discharge. The design flood discharge used is derived from rainfall data which is analyzed by frequency analysis, then the Nakayasu synthetic unit hydrograph (HSS) method is used to transform rain into the flow. Nakayasu Synthetic Unit Hydrograph is a synthetic unit hydrograph model or commonly abbreviated as HSS is a rain-discharge transformation model which is based on the hydrograph theory of hydrograph units produced by one unit of rain due to evenly distributed rain throughout the watershed with a certain duration, using watershed parameters as the basis for building the model.

The idea of arranging and selecting HSS is based on limited hydrological and hydrometric data so that the flow hydrograph is more represented by the characteristics of the watershed itself chosen in this study because the HSS development area is very close to the research location. It is expected that the analysis results obtained will represent and get the closest results.

A flood plain is a river control area defined based on flood discharge for at least a 50-year return period without embankments [25]. The results of the calculation of the flood discharge by the Nakayasu HSS method in Table 2 and Figure 6. 
Table 2: The scale of the American Society of Testing Material (ASTM).

\begin{tabular}{|c|c|c|c|c|c|c|c|c|c|c|}
\hline \multirow[t]{2}{*}{$\mathrm{T}$} & \multirow[t]{2}{*}{$\mathrm{UH}$} & \multicolumn{9}{|c|}{ Period (T-Years) } \\
\hline & & 1.01 & 2 & 5 & 10 & 25 & 50 & 100 & 200 & 1000 \\
\hline 0 & 0.000 & 0.000 & 0.000 & 0.000 & 0.000 & 0.000 & 0.000 & 0.000 & 0.000 & 0.000 \\
\hline 1 & 3.147 & 46.844 & 89.366 & 97.990 & 120.337 & 132.874 & 141.302 & 149.036 & 156.256 & 171.806 \\
\hline 2 & 12.230 & 211.554 & 403.586 & 442.536 & 543.455 & 600.072 & 638.137 & 673.064 & 705.672 & 775.897 \\
\hline 3 & 6.774 & 238.028 & 454.091 & 497.915 & 611.463 & 675.165 & 717.994 & 757.291 & 793.979 & 872.993 \\
\hline 4 & 3.848 & 226.898 & 432.859 & 474.633 & 582.873 & 643.596 & 684.422 & 721.881 & 756.855 & 832.173 \\
\hline 5 & 2.595 & 211.444 & 403.376 & 442.305 & 543.172 & 599.760 & 637.805 & 672.713 & 705.304 & 775.493 \\
\hline 6 & 1.750 & 180.190 & 343.752 & 376.926 & 462.884 & 511.107 & 543.529 & 573.277 & 601.051 & 660.864 \\
\hline 7 & 1.189 & 109.886 & 209.632 & 229.863 & 282.283 & 311.691 & 331.463 & 349.604 & 366.541 & 403.018 \\
\hline 8 & 0.885 & 71.755 & 136.888 & 150.099 & 184.328 & 203.532 & 216.443 & 228.289 & 239.349 & 263.168 \\
\hline 9 & 0.658 & 50.150 & 95.672 & 104.905 & 128.829 & 142.250 & 151.274 & 159.553 & 167.283 & 183.930 \\
\hline 10 & 0.490 & 35.728 & 68.160 & 74.738 & 91.782 & 101.344 & 107.772 & 113.671 & 119.178 & 131.038 \\
\hline 11 & 0.365 & 26.011 & 49.621 & 54.410 & 66.818 & 73.779 & 78.459 & 82.753 & 86.762 & 95.396 \\
\hline 12 & 0.271 & 19.357 & 36.929 & 40.493 & 49.727 & 54.907 & 58.390 & 61.586 & 64.570 & 70.996 \\
\hline 13 & 0.202 & 14.406 & 27.483 & 30.135 & 37.008 & 40.863 & 43.455 & 45.834 & 48.054 & 52.836 \\
\hline 14 & 0.150 & 10.721 & 20.453 & 22.427 & 27.542 & 30.411 & 32.340 & 34.110 & 35.763 & 39.322 \\
\hline 15 & 0.112 & 7.979 & 15.222 & 16.691 & 20.497 & 22.632 & 24.068 & 25.385 & 26.615 & 29.264 \\
\hline 16 & 0.083 & 5.938 & 11.328 & 12.422 & 15.254 & 16.843 & 17.912 & 18.892 & 19.808 & 21.779 \\
\hline 17 & 0.062 & 4.419 & 8.431 & 9.244 & 11.353 & 12.535 & 13.330 & 14.060 & 14.741 & 16.208 \\
\hline 18 & 0.046 & 3.289 & 6.274 & 6.880 & 8.449 & 9.329 & 9.921 & 10.464 & 10.971 & 12.062 \\
\hline 19 & 0.034 & 2.448 & 4.669 & 5.120 & 6.288 & 6.943 & 7.383 & 7.787 & 8.165 & 8.977 \\
\hline 20 & 0.026 & 1.822 & 3.475 & 3.810 & 4.679 & 5.167 & 5.495 & 5.795 & 6.076 & 6.681 \\
\hline 21 & 0.019 & 1.356 & 2.586 & 2.836 & 3.483 & 3.845 & 4.089 & 4.313 & 4.522 & 4.972 \\
\hline 22 & 0.014 & 1.009 & 1.925 & 2.110 & 2.592 & 2.862 & 3.043 & 3.210 & 3.365 & 3.700 \\
\hline 23 & 0.011 & 0.751 & 1.432 & 1.571 & 1.929 & 2.130 & 2.265 & 2.389 & 2.505 & 2.754 \\
\hline \multicolumn{2}{|c|}{ of the flood } & 238.028 & 454.091 & 497.915 & 611.463 & 675.165 & 717.994 & 757.291 & 793.979 & 872.993 \\
\hline
\end{tabular}

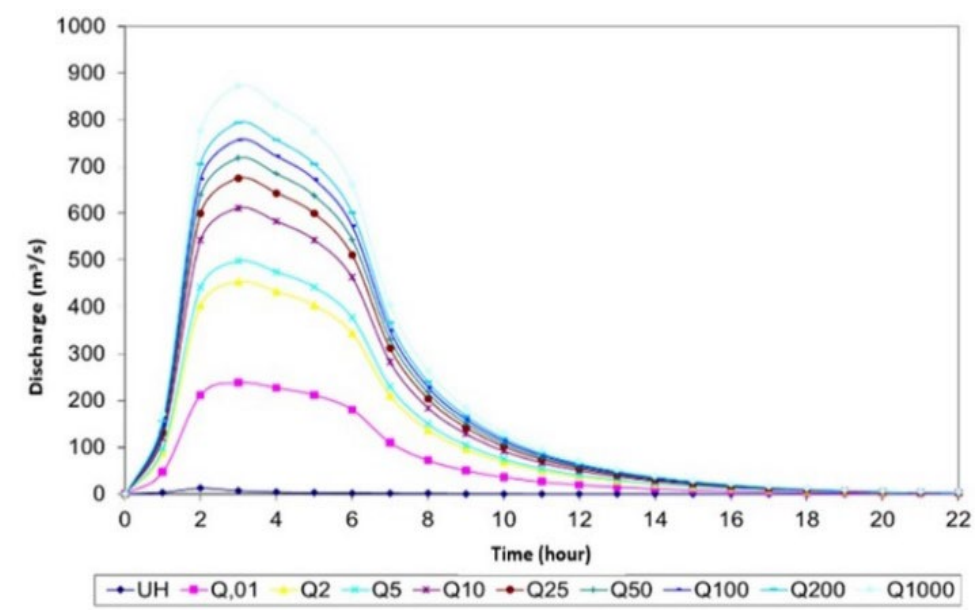

Figure 6: Graph of HSS Nakayasu.

\subsection{GEOMETRY ANALYSIS OF SIDOAN RIVER}

The design of flood analysis by considering the characteristics of the watershed, first identifies several parameters, including the length of the research river $(L)$, namely, the data obtained is $3,641.8 \mathrm{~m}$. and the area of the river basin (A) of the Sidoan River is $157.11 \mathrm{~km}^{2}$ according to Figure 7. 


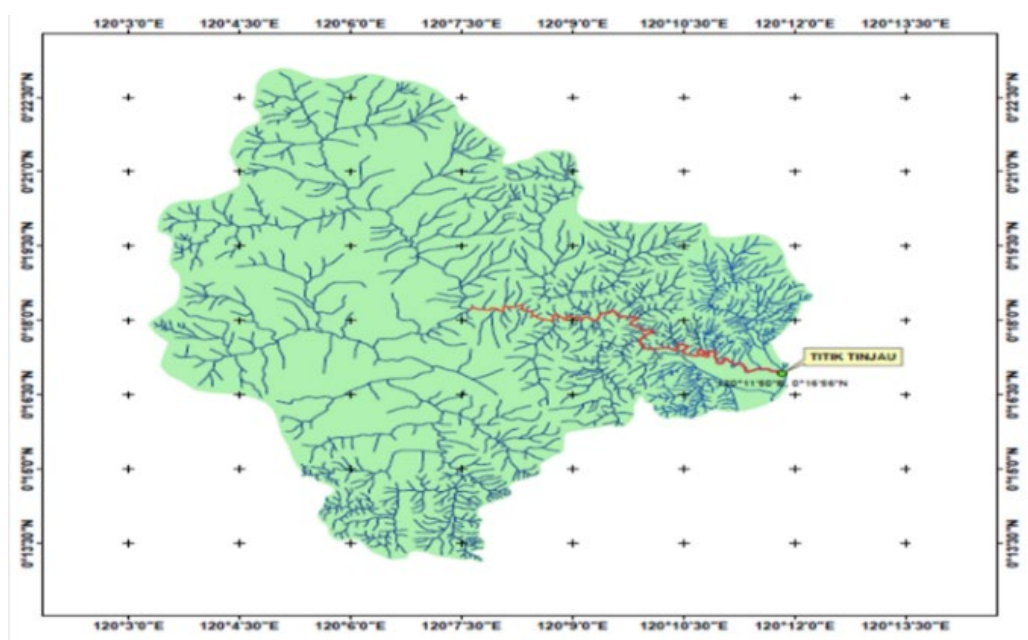

Figure 7: Map of Watershed Sidoan.

This research examines the character of the river bends. River bends are classified based on the results of field measurements processed with software HEC RAS 5.0 to get the bend character on $\mathrm{Q}_{50}$. The study took 5 bends, namely, bend 1 at STA. 43, bend 2 at STA. 33, bend 3 at STA. 22, bend 4 at STA. 12 and bend 5 at STA. 7, more details can be seen in Figure 8.

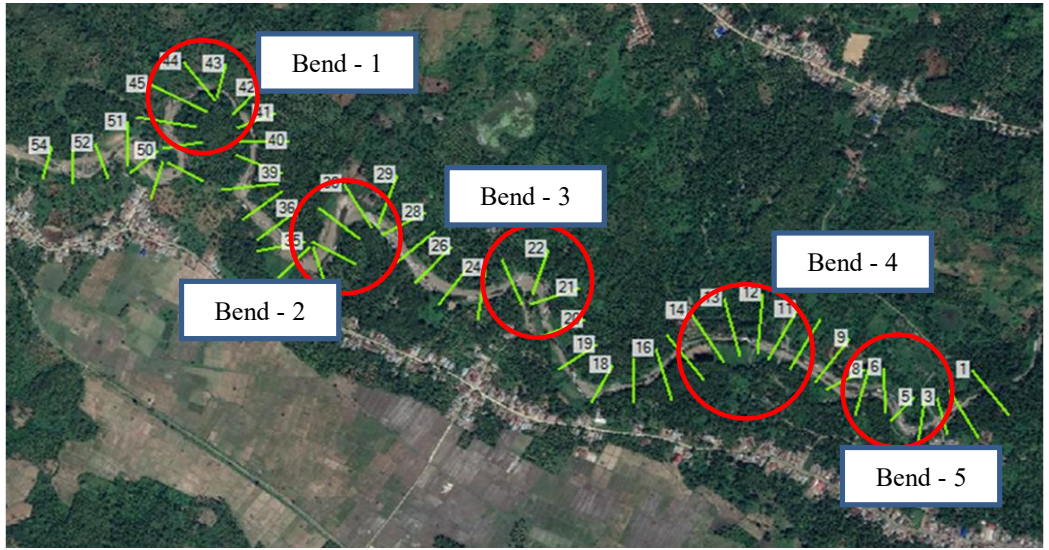

Figure 8: The situation of geometric STA. of the Sidoan River at STA. 1 - 54.

Bend 1 the observation point is at STA. 43 path length 403 m from STA. 46 until STA. 41, the magnitude of the bend angle $172^{\circ}$, axis length of the bend $348.72 \mathrm{~m}$, the length of the bend radius $338 \mathrm{~m}$.

Bend 2 the observation point is at STA. 33 path length $219 \mathrm{~m}$ from STA. 35 until STA. 32, the magnitude of the bend angle $93^{\circ}$, axis length of the bend $201 \mathrm{~m}$, the length of the bend radius $313.2 \mathrm{~m}$.

Bend 3 the observation point is at STA. 22 path length $162.3 \mathrm{~m}$ from STA. 23 until STA. 21, the magnitude of the bend angle $162^{\circ}$, axis length of the bend $112 \mathrm{~m}$, the length of the bend radius $412 \mathrm{~m}$.

Bend 4 the observation point is at STA. 12 path length $402.7 \mathrm{~m}$ from STA. 13 until STA. 11 with the magnitude of the bend angle $140^{\circ}$, axis length of the bend $233 \mathrm{~m}$, the length of the bend radius $418 \mathrm{~m}$.

Band 5 the observation point is at STA. 7 path length 119 m from STA. 8 until STA. 6 and with the magnitude of the bend angle $63^{\circ}$, axis length of the bend $86 \mathrm{~m}$, the length of the bend radius $320 \mathrm{~m}$.

\subsection{ANALYSIS OF MEANDERING}

Based on the measurement results in the field and the calculation results obtained are as stated in Table 3. 
Table 3: Data of Hydraulic Sidoan River.

\begin{tabular}{|c|c|c|c|c|c|c|c|}
\hline \multirow{2}{*}{ STA. } & $\mathrm{Q}_{50}$ & $\mathrm{~h}$ & $\mathrm{U}$ & $\mathrm{B}$ & $\mathrm{I}$ & $\mathrm{d}_{50}$ & Froude \\
\cline { 2 - 8 } & $\left(\mathrm{m}^{3} / \mathrm{s}\right)$ & $(\mathrm{m})$ & $(\mathrm{m} / \mathrm{s})$ & $(\mathrm{m})$ & $(-)$ & $(\mathrm{m})$ & $(-)$ \\
\hline 43 & 717.9 & 3.83 & 4.08 & 112.1 & 0.005 & 0.014 & 0.70 \\
\hline 33 & 717.9 & 4.32 & 2.44 & 104.4 & 0.005 & 0.014 & 0.39 \\
\hline 22 & 717.9 & 3.80 & 3.58 & 133.6 & 0.005 & 0.013 & 0.61 \\
\hline 12 & 717.9 & 4.01 & 3.61 & 139.2 & 0.005 & 0.014 & 0.60 \\
\hline 7 & 717.9 & 3.96 & 3.31 & 104.4 & 0.005 & 0.012 & 0.56 \\
\hline
\end{tabular}

The parameters of the ratio of curvature and width of the river are deflected (R/W) can be used as a tool to predict the rate of erosion in river bends [26]. In general, the erosion behavior for river bend conditions is stated as follows, therefore $3 \leq \mathrm{R} / \mathrm{W} \leq 5$, thus sharp bends are bends 1,3 , and 5 , others are non-sharp bends.

Table 4: Result of Measurement and Calculation of Meandering in Sidoan River.

\begin{tabular}{|c|c|c|c|c|c|c|c|}
\hline Bend & Station & $\mathrm{SI}$ & $\mathrm{R} / \mathrm{B}$ & $\mathrm{B} / \mathrm{H}$ & $\mathrm{U} *$ & $\frac{U_{*}^{2}}{\triangle g d}$ & $R_{e_{*}}=\frac{U_{*} d}{v}$ \\
\hline & & & - & - & $\mathrm{m} / \mathrm{s}$ & - & - \\
\hline 1 & 43 & 1.30 & 3.01 & 33.16 & 0.45 & 0.883 & 4814 \\
\hline 2 & 33 & 1.78 & 2.00 & 24.20 & 0.46 & 0.935 & 4957 \\
\hline 3 & 22 & 2.50 & 3.08 & 35.16 & 0.43 & 0.880 & 4317 \\
\hline 4 & 12 & 1.19 & 2.90 & 34.71 & 0.44 & 0.870 & 4776 \\
\hline 5 & 7 & 1.30 & 3.06 & 26.36 & 0.44 & 1.000 & 4068 \\
\hline
\end{tabular}

Value of $\Delta=\left(\rho_{\mathrm{s}}-\rho_{\mathrm{w}}\right) / \rho_{\mathrm{w}}$, the above results plotted on the Shields graph $\mathrm{x}$-axis is $\mathrm{R}_{\mathrm{e}^{*}}=\mathrm{U} * \mathrm{~d} / v$ and the $\mathrm{y}$-axis is $\mathrm{U} * 2 / \Delta \mathrm{gd}$, resulting in all sediment moving as shown in Figure 9.

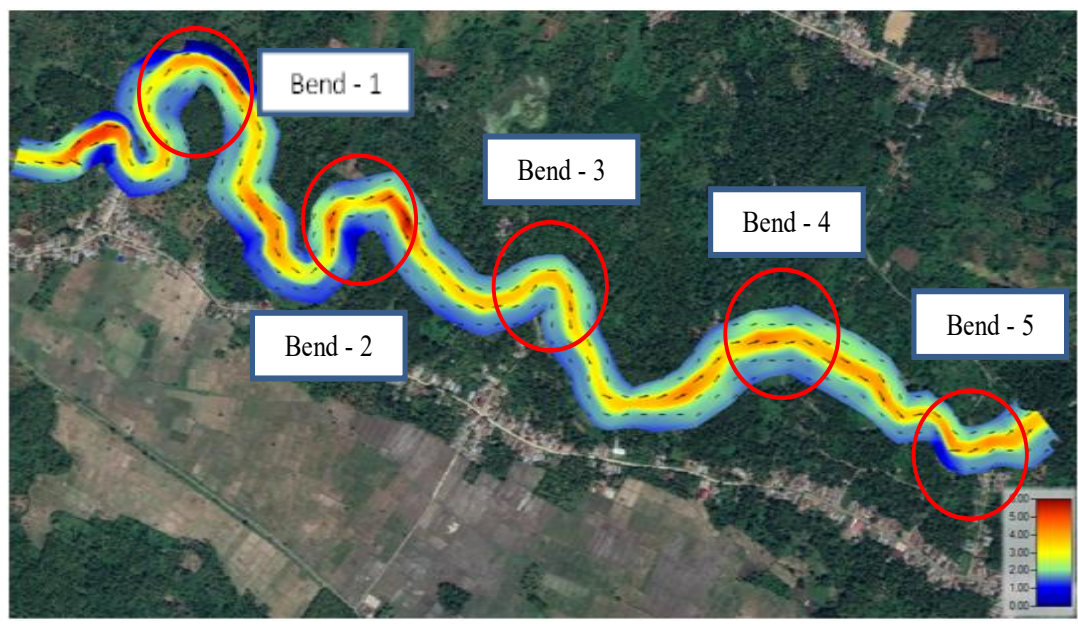

Figure 9: Water velocity simulation for $\mathrm{Q}_{50}$ in STA. 1 - STA. 54.

Bend that has a small angle bends 2, has a small velocity compared to bend 1, 3, 4, and 5 shown in Figure 10. 


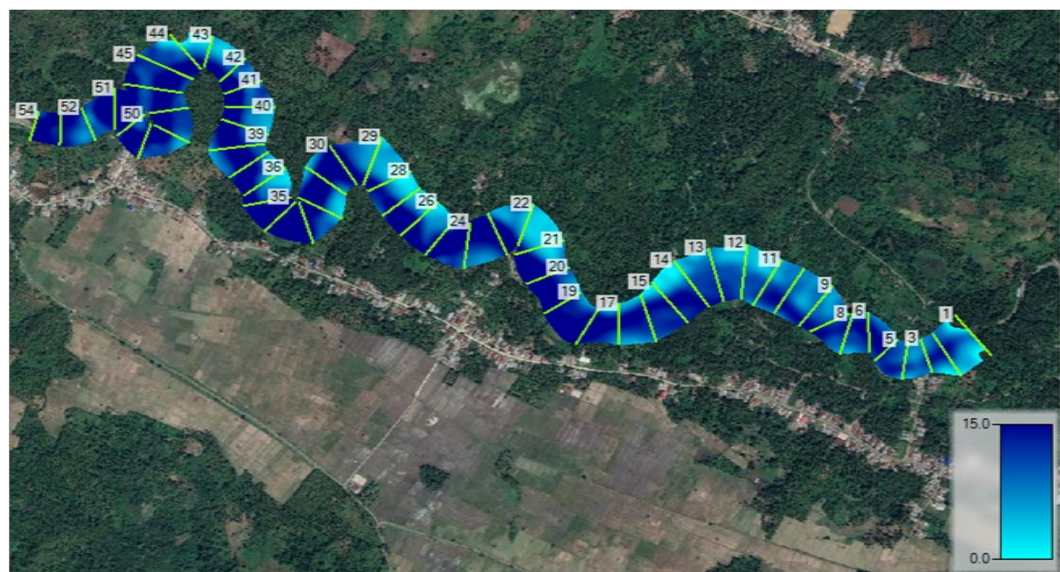

Figure 10: Depth simulation $Q_{50}$ in STA. 1 - STA. 54.

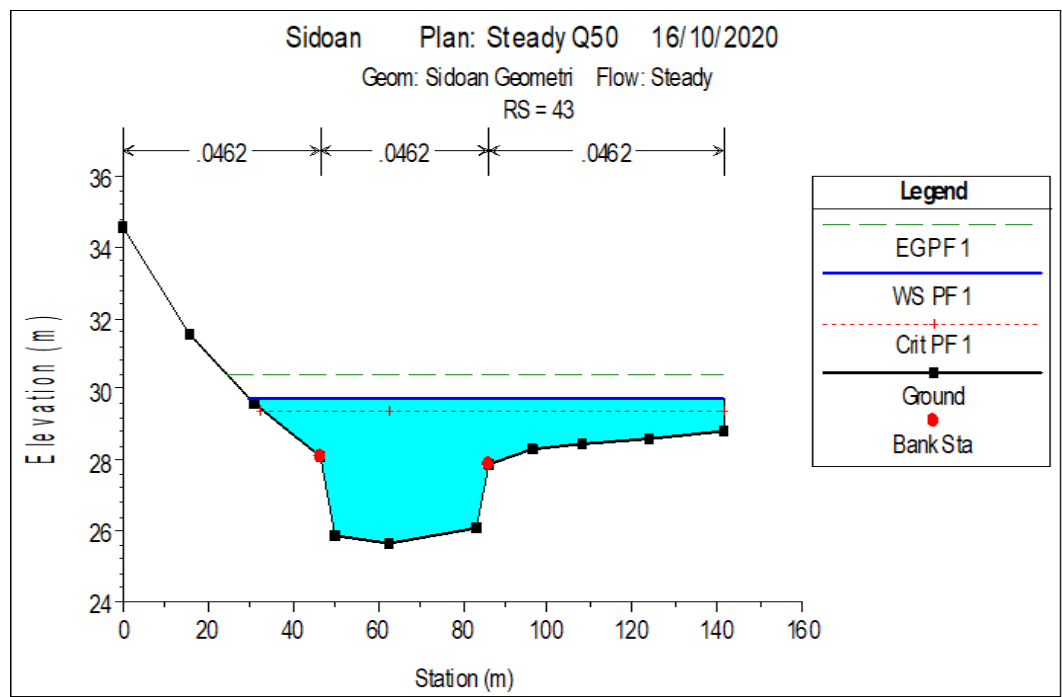

Figure 11: Cross-section bend 1.

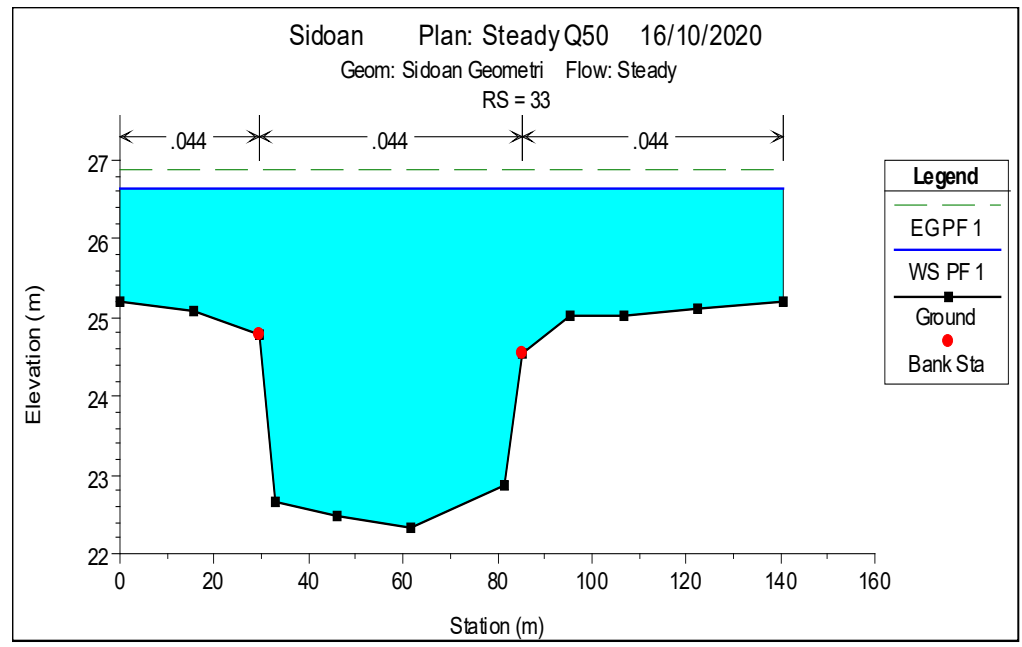

Figure 12: Cross-section bend 2 . 
Rinawati, M. Galib Ishak, and Rudi Herman

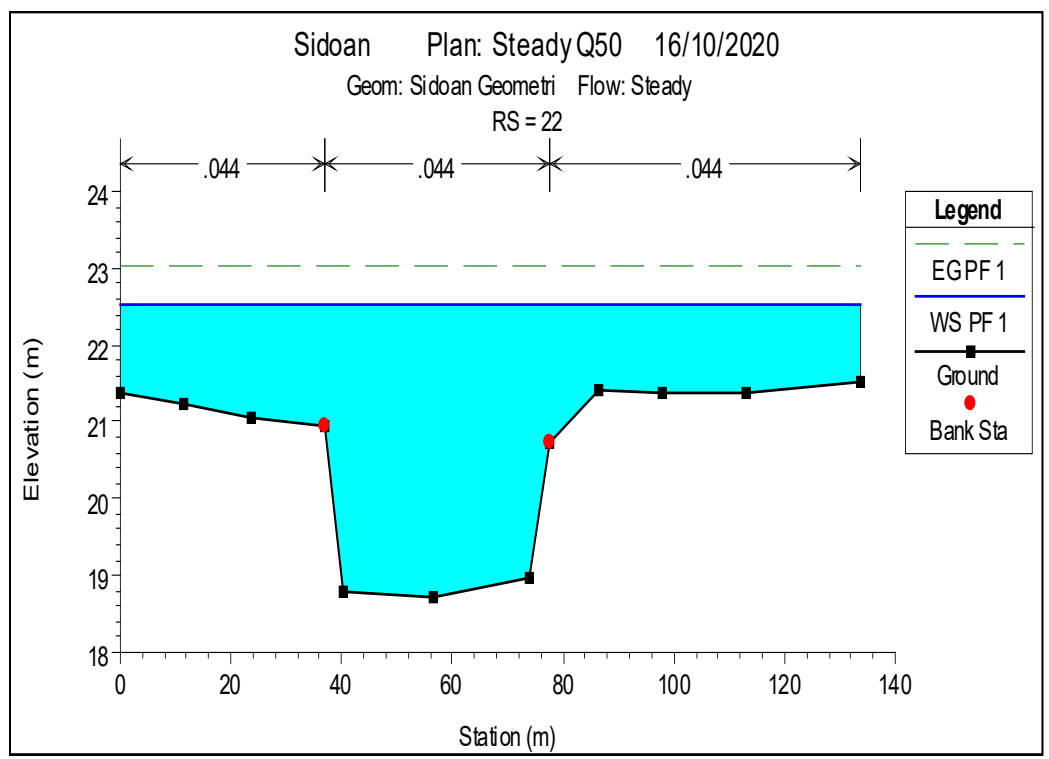

Figure 13: Cross-section bend 3.

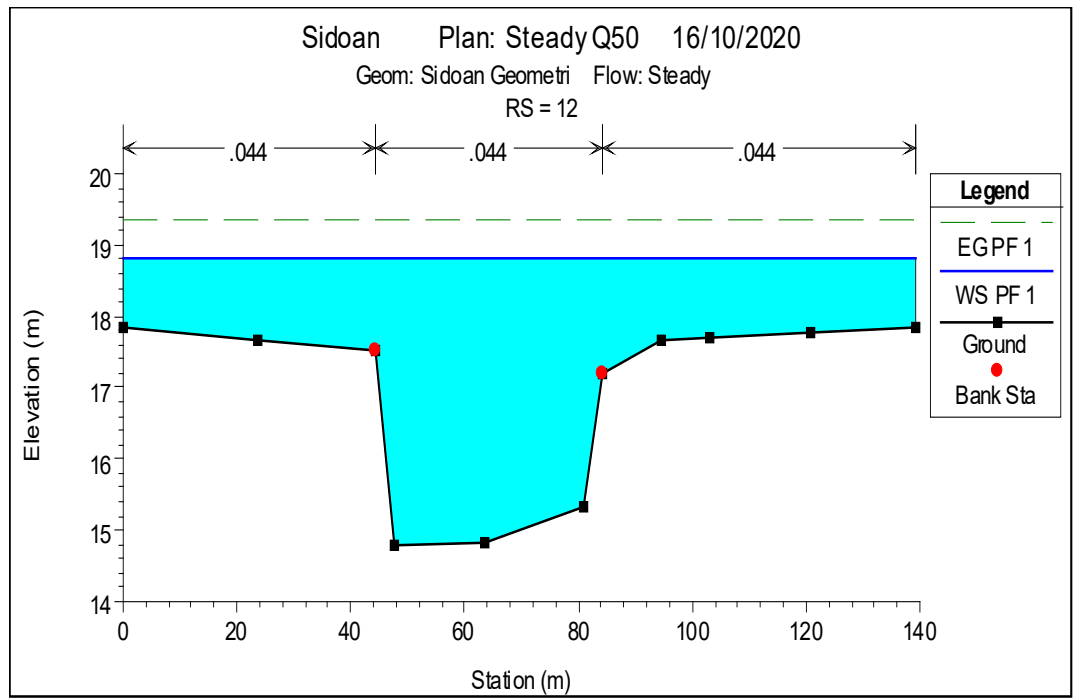

Figure 14: Cross-section bend 4 .

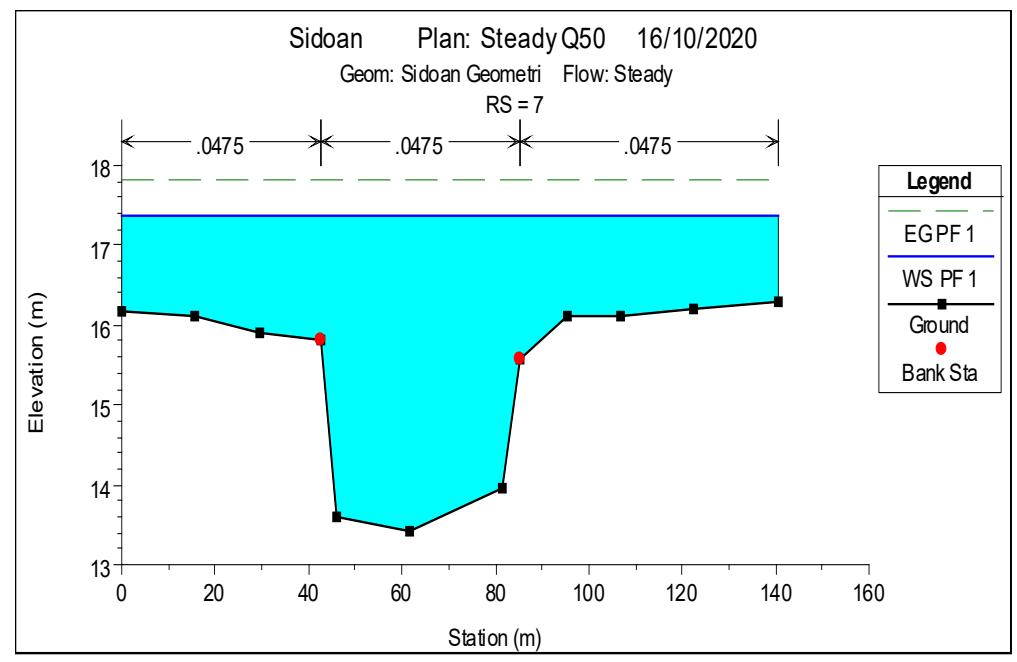

Figure 15: Cross-section bend 5 . 
The cross-section profile shows that the riverbed at bends $1,2,3,4$, and 5 the elevation of the river bed outside the bend is lower than the elevation on the inside of the bend as shown in Figure 11-15.

\section{CONCLUSIONS AND RECOMMENDATIONS}

This research was conducted on 5 adjacent bends, using Q50 the results show that all sediment on the outside of the bend is moving so there is a need for cliff countermeasures. the depth of flow at the bends $1,2,3,4$ and 5 respectively $3.83 \mathrm{~m}, 4.32 \mathrm{~m}, 3.8 \mathrm{~m}, 4.01 \mathrm{~m}$ and $3.96 \mathrm{~m}$. the magnitude of the shear velocity is $0.447 \mathrm{~m} / \mathrm{s}, 0.46 \mathrm{~m} / \mathrm{s}$, $0.43 \mathrm{~m} / \mathrm{s}, 0.44 \mathrm{~m} / \mathrm{s}, 0.44 \mathrm{~m} / \mathrm{s}$. Value of critical shear stress in bends $1,2,3,4$, and 5 respectively $199.89 \mathrm{~N} / \mathrm{m}^{2}, 211.8$ $\mathrm{N} / \mathrm{m}^{2}, 184.9 \mathrm{~N} / \mathrm{m}^{2}, 193.6 \mathrm{~N} / \mathrm{m}^{2}$ dan $193.6 \mathrm{~N} / \mathrm{m}^{2}$. The highest critical shear stress at the second bend. because in the second bend the critical shear velocity of the river bed is large. from these results, it can be concluded that the shear velocity is directly proportional to the shear stress.

\section{APPENDICES}

\begin{tabular}{|c|c|c|}
\hline Nomenclature & \multicolumn{2}{|c|}{} \\
\hline $\mathrm{A}$ & cross-section area & $\mathrm{m}^{2}$ \\
\hline $\mathrm{d}$ & diameter sediment & $\mathrm{m}$ \\
\hline $\mathrm{g}$ & acceleration of gravity & $\mathrm{m} / \mathrm{s}^{2}$ \\
\hline $\mathrm{I}_{\mathrm{t}}$ & intensity of rainfall for rain $\mathrm{t}$ & $\mathrm{mm} / \mathrm{hour}$ \\
\hline $\mathrm{n}$ & coefficient of Manning & $\mathrm{m}^{-1 / 3} / \mathrm{s}$ \\
\hline $\mathrm{Q}$ & discharge & $\mathrm{m}^{3} / \mathrm{s}$ \\
\hline $\mathrm{R}_{24}$ & 24-hour rainfall & $\mathrm{mm} / \mathrm{hour}$ \\
\hline $\mathrm{R}_{\mathrm{e}}$ & Reynold's number & - \\
\hline $\mathrm{t}$ & time & $\mathrm{hour}$ \\
\hline $\mathrm{u}^{*}$ & shear velocity & $\mathrm{m} / \mathrm{s}$ \\
\hline Greek letters & coefficient Shield & - \\
\hline$\theta_{\mathrm{c}}$ & critical shear stress & $\mathrm{KN} / \mathrm{m}^{3}$ \\
\hline$\tau_{\mathrm{r}}$ & grain specific gravity of sediment & $\mathrm{N} / \mathrm{m}^{2}$ \\
\hline$\rho_{\mathrm{s}}$ & grain specific gravity of water & $\mathrm{N} / \mathrm{m}^{2}$ \\
\hline$\rho_{\square}$ & \multicolumn{2}{c}{} \\
\hline
\end{tabular}

\section{SOURCES OF FUNDING}

This research received no specific grant from any funding agency in the public, commercial, or not-for-profit sectors.

\section{CONFLICT OF INTEREST}

The author have declared that no competing interests exist.

\section{ACKNOWLEDGMENT}

None.

\section{REFERENCES}

[1] Rinaldi and Yulistianto, B., Fidsil model of grind control around bridge abutment, University of Gajah Mada, Yogyakarta, 2002.

[2] Wiyono, A., Nugroho, J., Widyaningtyas, Zaidun, E.R., Comparison of local scouring that occurs around the abutment of vertical walls without wings and with wings on straight channels. bends at $90^{\circ}$ and $180^{\circ}, 2011$. 
[3] Kuncoro, D.H., Sungkono, Suptarita, Anwar, C., Estimated geometry of the river meandering from the magnitude of the discharge, Tesis ITS, Surabaya, 2013.

[4] Marttotorang, U.H., Study of the influence of river floor width on the characteristics of sediment flow at the base, Tesis University of Andi Djema Palopo, 2014.

[5] Hambali, R. and Apriyanti, Y., Sedimentary study of sedimentation rate of Daeng river, In FROPIL (Forum Profesional Teknik Sipil), Vol. 4, No. 2, 2019, 165-174.

[6] Ishak, M.G., Coefficient of superelevation for the flow using movable pillar in channel bend, International Journal of Engineering and Technology, Vol. 7, No. 6, 2015, 63-69.

[7] Suemi, Study of characteristics of sub-watersheds Landak in the Kapuas watershed of the river district Temila Landak district, 2016.

[8] Ishak, M.G., The effect of thickness of pillar in the channel bend to changes the coefficient of superelevation, Journal of Engineering Science and Technology, Publisher: Taylor's University College, Vol. 11, No. 5, 2016, 745-754.

[9] Purnama, A.K. and Aini, E. N., Flow characteristics on open channel bends, Tesis University of Samawa Sumbawa Besar, 2016.

[10] Kapoh, S.B., Halim, F., Hendratta, L.A., Analysis of sediment transport in the bend of Talawaan Bajo River in north Minahasa district, Jurnal Sipil Statik, University of Sam Ratulangi Manado, Vol. 7, No. 7, 2019.

[11] Froehlich, D.C., Local scour at bridge abutments. San Francisco. California: Proceedings. ASCE. National Hydraulics Conference, 1989, 922-927.

[12] Fasddarsyah, Analysis of riverbed sediment characteristics to depth parameters, Tesis University of Malikus Saleh, 2016.

[13] Hasdaryatmin, D., Study of the effect of river bends on the volume of scouring, Jurnal INTEK, Vol. 6, No 2, 2017.

[14] Chow, V.T., Open channel hydraulics, Publisher: Erlangga, Jakarta, 1989.

[15] Triatmodjo, B., Port planning, Publisher Beta Offset, Yogyakarta, 2009.

[16] Subarkah, I., Hydrology for water building planning, Bandung, 1980.

[17] 'Hay, R., Geology of the Olduvai George: a study of sedimentation in a semiarid basin, Pp. 203, University of California Press, Berkeley-Los Angeles-London. 1996.

[18] Leopold, L.B., Water surface topography in river channels and implications for mender development. gravelbed river. Edited by R. D. Hey, J. C. Bathurst, and C. R. Thorne, John Wiley \& Sons Ltd, 1982.

[19] Morisawa M. and Longman, Rivers: Form and process (Geomorphology texts), 1985.

[20] van Rijn, L.C., Handbook sediment transport by currents and waves", Delft Hydraulic, 1989.

[21] Hydrologic Engineering Center (HEC), EC-RAS River analysis system, User's Manual, US Army Corps of Engineers, 2010.

[22] Meyer, E., Peter, and Müller, R., Formulas for bedload transport, paper presented at 2nd Meeting, Int. Assoc. for Hydraulics, Environ. Eng. and Res. Madrid, 1948.

[23] Subramanya, K., Flow in open channels, Publisher: McGraw-Hill Publishing Co. New Delhi, 2007.

[24] Henderson, Open channel flow, Publisher: MacMillan Series in Civil Engineering, 1996.

[25] Regulation of the Minister of Public Works (RMPW), River borderline, river benefit area, river control area, and the former river, No.: 63/PRT/1993.

[26] arde, R.J, River morphology, New Age International Ltd. New Delhi, 502, 2006. 